
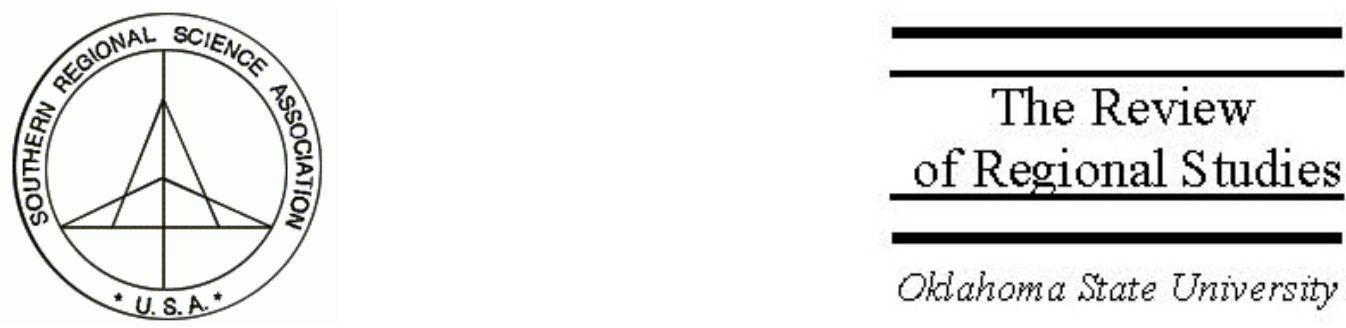

\title{
Proprietorship Formations and U.S. Job Growth
}

\author{
Sundar S. Shrestha \\ The Northeast Regional Center for Rural Development and Department of Agricultural \\ Economics and Rural Sociology, The Pennsylvania State University, \\ State College, PA 16802, e-mail: sss190@psu.edu
}

\section{Stephan J. Goetz}

Department of Agricultural Economics and Rural Sociology and Director, The Northeast Regional Center for Rural Development, The Pennsylvania State University, State College, PA 16802,e-mail: sgoetz@psu.edu

\section{Anil Rupasingha}

Department of Agricultural Economics and Agricultural Business, New Mexico State University, Las Cruces, NM 88003-8003,e-mail: anilr@nmsu.edu

\footnotetext{
Abstract

Despite the surging interest in entrepreneurship as an economic development strategy, studies of the independent relationship between proprietorship formations and job growth are virtually nonexistent. We find that self-employment or proprietorship rates are associated with faster job growth in the wage-and-salary sector, and the effect is statistically significant. The relative magnitude of this effect varies with the business cycle, being stronger during economic expansions and weaker during contractions. Further, the effect is stronger in metropolitan than in non-metropolitan counties.
}

Keywords: Employment growth; Self employment; Spatial spill-over

JEL classification: J21; R11; 018 


\section{INTRODUCTION}

Interest among policy-makers, practitioners, and academics in proprietorships and self-employment as sources of economic development has increased dramatically in recent years (Evans and Leighton 1989; Malecki 1990; Reynolds, Storey, and Westhead 1994; Parker 1996; Hamilton 2000; Goetz and Freshwater 2001; Armington and Acs 2002; Georgellis and Wall 2006; Sobel and Dean 2006; Goetz and Rupasingha 2007). This interest largely stems from the fact that many communities have lost major employers in manufacturing and natural resource-based industries to the twin forces of globalization and technological advances. Most if not all of these communities will not be able to compensate for the resulting job losses by recruiting new firms from the outside. Instead, they have to look internally to entrepreneurship and self-employment if they wish to remain economically vibrant. In fact, one of the most remarkable but least noticed trends nationwide has been a steady increase in non-farm proprietor employment shares since 1969.

Given the strong interest in proprietors, the relative dearth of studies in the U.S. on the effect of these workers on total job growth is surprising. Previous studies primarily focused on the effects of unemployment compensation insurance, worker's compensation insurance, unionization, socio-demographic factors, birth and deaths of establishments, and industry specialization on job growth (Greenwood 1980; Gillis and Shahidsaless 1981; Long 1993; Hammond and Thompson 2004; Edmiston 2006). Studies of the extent to which proprietorship formation affects overall local job growth in the U.S. are limited, with the important exception of Atasoy, McConnon, and Gabe (2004). In Europe, a number of authors have investigated this question (Davidsson, Lindmark, and Olofsson 1994; Van Stel and Storey 2004; Baptista, Escaria, and Madruga 2005; Mueller, Van

Stel, and Storey 2006). Our study is similar to that of Atasoy, McConnon, and Gabe (2004) and Van Stel and Storey (2004) but differs by the scope and analytical methods used.

Questions about the effect of proprietors on job creation are not trivial. For example, such firms could out-compete and displace existing firms, especially if they are initially subsidized, producing no net new jobs. Or they could create competitive pressures that increase the economic viability of a region, leading to future job growth. Whether one factor outweighs the other must be answered empirically.

This study adds to the labor market and regional development literatures in several significant ways. To our knowledge, this is the first study to systematically and comprehensively test for the effect of proprietorship formations on overall job creation in the U.S. economy. Other innovations introduced include spatial tests for auto-correlation across counties as well as an expanded set of relevant covariates as controls. 


\section{PROPRIETORSHIP FORMATIONS IN THE U.S.}

We define proprietorship formation as growth in the numbers of non-farm proprietors during the periods studied. According to the Bureau of Economic Analysis (BEA), U.S. Department of Commerce, local estimates of non-farm proprietors' employment "consist of the number of sole proprietorships and the number of individual business partners not assumed to be limited partners." We examine only non-farm proprietorships since profound differences exist between the farm and non-farm sectors, ranging from fixed asset requirements and unique skills sets to laws and regulations, such as bankruptcy laws and tax accounting rules (see also Georgellis and Wall 2006).

An important trend in the last three decades has been the increase in non-farm proprietorships (NFPE). Figure 1 illustrates this growth between 1969 and 2004 (base year $1969=100)$. The figure also shows the growth in non-farm wage and salary employment (NFWSE). Over the 36-year period, non-farm proprietor's employment increased by an annual average of 3.2 percent $\left[\operatorname{lnNFPE} E_{t}=16.063+0.032\right.$ Year $\left._{t}\right]$. During the same period, non-farm wage and salary employment increased by an annual average of 1.8 percent $\left[\operatorname{lnNFWSE} \mathrm{t}_{\mathrm{t}}=18.145+0.018\right.$ Year $\left._{\mathrm{t}}\right]$.

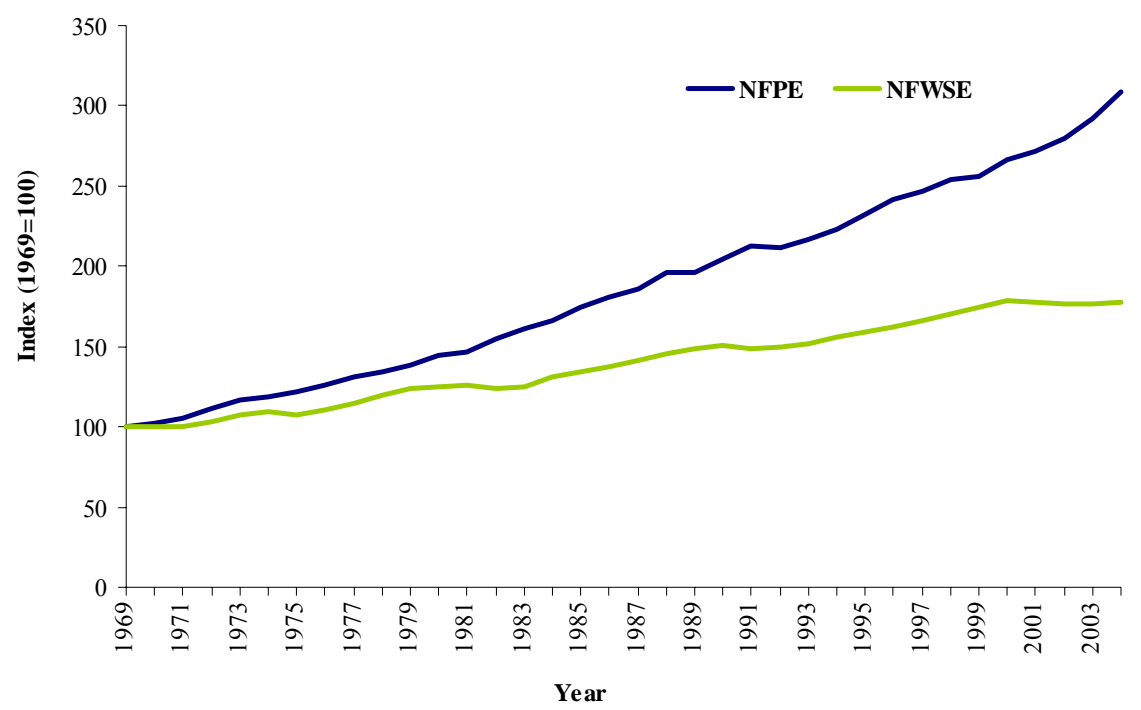

FIGURE 1 Trends of Non-Farm Proprietors' Employment and Non-Farm Wage and Salary Employment in the U.S., 1969-2004 (1969 = 100)

\footnotetext{
${ }^{1}$ Source: www.bea.gov/regional/definitions/nextpage.cfm?key=Proprietors\%20employment Accessed September 10, 2007.
} 
The significant growth in non-farm proprietorships is attributed to several factors, including a decline in the numbers of farm-proprietorships (Goetz and Debertin 2001), a shrinking workforce in manufacturing and large firms induced by information technology (Johnson 2001), preferences for natural amenities (Deller, Tsai, Marcouiller, and English 2001) and other factors (Goetz and Rupasingha 2007).

\section{THEORETICAL FRAMEWORK}

Job growth in a region is a function of job creation and destruction over specific periods. These in turn are related to the births and deaths of firms, their expansions and contractions as well as relocations (Essletzbichler 2004; Neumark, Zhang, and Wall 2005). Our data does not allow us to examine the individual components of job growth, but we can examine the relationship between growth in overall proprietorships and jobs using the net county-level data. Fritsch and Mueller (2004) theorize that the formation of new firms has three possible effects (also see Van Stel and Storey 2004; Baptista, Escaria, and Madruga 2005; Mueller, Van Stel, and Storey 2006). First are the direct employment effects of a firm's formation that lead to additional employment because proprietors themselves demand local goods and services. Second are the negative employment effects (displacement effects) stemming from the destruction of incumbent firms and resulting job losses as new, more profitable and less labor-intensive starts-ups enter an industry. Third are the positive employment effects that arise from supply-side spillover (induced effects) when new proprietors cause increased competition and improved performance among existing firms in the county or region. Thus, the net effect of proprietorship formations on job growth cannot be determined in advance.

To the extent that proprietors are a relatively small portion of the economy, they may not exert a statistically significant effect on total job growth. Furthermore, if these new firms are created only as a result of subsidies, they may actually undermine local competitiveness; and this will result in fewer jobs as the proprietorships are dissolved once the subsidies are removed. Similarly, the supply-side spill-over effect may not be significant if the increased competition and survival of the fittest of firms does not expand the market (Baptista, Escaria, and Madruga 2005). Hence, the magnitude of any positive supply-side effect largely depends on the innovativeness and efficiency of the new firms and how existing firms respond to new arrivals.

The literature provides mixed evidence about the relationship between proprietorship formation and job growth. While Acs and Armington (2004) and Folster (2000) report positive effects of new firm formation on employment, Van Stel and Storey (2004), using U.K. data, show that the effect of new firm formation on net job growth is not always positive. They obtained different results across time periods and regions (Scotland, England, and Wales). 


\section{EMPIRICAL STRATEGY}

\subsection{Data}

The U.S. county-level data used in this study are primarily from the Regional Economic Information System (REIS), the U.S. Bureau of Economic Analysis (bea.gov/bea/regional/reis/), and U.S. Census Bureau. The BEA provides county-level regional economic profiles from 1969 to 2004 . We use data from 3,035 counties for various sub-periods during 1985-2004 and exclude Hawaii, Alaska, and Washington, D.C. Of these counties, 26.2 percent in 1993 were designated metropolitan as defined by the Economic Research Services (ERS) of the United States Department of Agriculture (USDA), and this share increased to 34.2 percent by 2003 . The variables, their descriptions, and data sources are reported in Table 1.

Over the 1985-1989 period, the average county-level job growth rate was 9.3 percent; it declined to 8.4 percent in 1990-1994 and 7.0 percent in 1995-1999, while in 2000-2004 it was only 0.54 percent, producing the so-called "jobless recovery." The share of counties that experienced positive growth followed a similar pattern. In the first three periods considered, about 80 percent of counties experienced positive job growth; in 2000-2004 this share declined to 50 percent. In the case of proprietorship growth, the opposite pattern was observed. Non-farm proprietorship formations relative to the total workforce in the beginning year of the period increased as follows: from 0.98 percent in 1985-1989 to 2.13 percent in 1990-1994, 2.30 percent in 1995-1999 and 2.28 percent in 2000-2004.

\subsection{Empirical Model, Hypotheses, and Motivation}

We adapt and extend the work of Van Stel and Storey (2004) to the U.S. context. The time periods are split into three sub-periods of five years each: 2000-2004, 1995-1999, and 1990-1994 for the dependent variable and 1995-1999, 1990-1994, and 1985-1989 for the key independent variables. ${ }^{2}$ For the key independent variables we use five-year lags, since the impact of a new firm's formation is not immediate. We assume that in five years the impact will be measurable if one exists, although the lag of five years may not capture all effects. Van Stel and Storey (2004) found that the impact of a new firm's formation on employment growth is at a maximum after four-and-a-half years.

For each time period we estimated the base model as in Van Stel and Storey (2004), regressing the percent change in non-farm wage-and-salary employment in U.S. counties

\footnotetext{
${ }^{2}$ These periods do not match perfectly the national business cycle, which plays out to varying degrees (and over different periods) within individual counties, making exact dating difficult if not impossible. We chose time intervals that are of the same length rather than track the national business cycle closely.
} 
Shrestha/Goetz/Rupasingha: Proprietorship Formations and U.S. Job Growth

\section{TABLE 1}

Variables, Descriptive Statistics and Data Sources

\begin{tabular}{|c|c|c|c|c|}
\hline Variables & Mean & SD & Min & Max \\
\hline $\begin{array}{l}\text { \% change in non-farm wage and salary } \\
\text { employment, } 2000-2004^{1}\end{array}$ & 0.536 & 8.723 & -48.889 & 63.694 \\
\hline $\begin{array}{l}\text { \% change in non-farm wage and salary } \\
\text { employment, } 1995-1999^{1}\end{array}$ & 7.011 & 10.390 & -33.082 & 247.360 \\
\hline $\begin{array}{l}\% \text { change in non-farm wage and salary } \\
\text { employment, } 1990-1994^{1}\end{array}$ & 8.442 & 22.338 & -58.214 & $1,003.68$ \\
\hline $\begin{array}{l}\% \text { change in Non-farm wage and salary } \\
\text { employment, } 1985-1989^{1}\end{array}$ & 9.258 & 14.278 & -77.108 & 296.598 \\
\hline $\begin{array}{l}\% \text { change in no. of non-farm proprietors } \\
\text { per total employment, } 1995-1999^{1}\end{array}$ & 2.298 & 5.125 & 24.779 & 46.293 \\
\hline $\begin{array}{l}\% \text { change in no. of non-farm proprietors } \\
\text { per total employment, } 1990-1994^{1}\end{array}$ & 2.133 & 2.981 & -7.975 & 42.207 \\
\hline $\begin{array}{l}\% \text { change in no. of non-farm proprietors } \\
\text { per total employment, } 1985-1989^{1}\end{array}$ & 0.979 & 3.143 & -18.844 & 25.191 \\
\hline $\begin{array}{l}\% \text { change in average wage and salary } \\
\text { earnings, } 1995-1999^{1}\end{array}$ & 16.060 & 6.468 & -12.890 & 141.590 \\
\hline $\begin{array}{l}\% \text { change in average wage and salary } \\
\text { earnings, } 1990-1994^{1}\end{array}$ & 14.786 & 5.991 & -29.870 & 54.800 \\
\hline $\begin{array}{l}\% \text { change in average wage and salary } \\
\text { earnings, } 1985-1989^{1}\end{array}$ & 14.332 & 7.982 & -29.580 & 71.350 \\
\hline $\begin{array}{l}\text { Metropolitan county (Beale code), } 2003 \\
\quad(\text { yes }=1)^{3}\end{array}$ & 0.342 & 0.475 & 0.000 & 1.000 \\
\hline $\begin{array}{l}\text { Metropolitan county (Beale code), } 1993 \\
\quad(\text { yes }=1)^{3}\end{array}$ & 0.262 & 0.440 & 0.000 & 1.000 \\
\hline $\begin{array}{l}\% \text { population } 25+\text { years with at least } \\
\text { bachelor's degree, } 2000^{2}\end{array}$ & 16.365 & 7.600 & 4.921 & 60.482 \\
\hline$\%$ population foreign born, $2000^{2}$ & 3.391 & 4.733 & 0.000 & 46.127 \\
\hline Ethnic diversity index, $2000^{2}$ & 0.215 & 0.171 & 0.000 & 0.702 \\
\hline Share of vote for Bush, $2000^{7}$ & 57.092 & 11.887 & 11.770 & 92.470 \\
\hline $\begin{array}{l}\text { Per capita unemployment insurance } \\
\text { compensation }(\$), 2000^{1}\end{array}$ & 71.828 & 45.146 & 0.000 & 381.000 \\
\hline Social capital index, $1997^{2,4,5}$ & -0.012 & 1.273 & -4.063 & 7.656 \\
\hline High-tech establishments, $1999^{4}$ & 52.444 & 269.57 & 0.000 & $7,927.00$ \\
\hline Number of broadband suppliers ${ }^{6}$ & 17.054 & 66.26 & 0.000 & $1,949.00$ \\
\hline $\begin{array}{l}\text { Spatial weight*Number of broadband } \\
\text { suppliers }^{6}\end{array}$ & 17.589 & 44.455 & 0.000 & 707.75 \\
\hline Number of Wal-Mart stores, $1998^{8}$ & 0.929 & 1.590 & 0.000 & 27.000 \\
\hline Industry diversity index, $2000^{2}$ & 0.781 & 0.034 & 0.531 & 0.849 \\
\hline Amenity scale (McGranahan) ${ }^{3}$ & 0.045 & 2.285 & -6.400 & 11.170 \\
\hline $\begin{array}{l}\text { County with highway connection, } 2000 \\
\qquad(\text { yes }=1)^{9}\end{array}$ & 0.427 & 0.495 & 0.000 & 1.000 \\
\hline $\begin{array}{l}\text { Non-farm wage and salary employment, } \\
1985^{1}\end{array}$ & $32,838.879$ & $132,283.475$ & 62.000 & $4,095,767.000$ \\
\hline
\end{tabular}




\begin{tabular}{|c|c|c|c|c|}
\hline Variables & Mean & SD & Min & Max \\
\hline $\begin{array}{l}\text { Non-farm wage and salary employment, } \\
1990^{1}\end{array}$ & $36,717.598$ & $144,355.580$ & 24.000 & $4,547,337.000$ \\
\hline $\begin{array}{l}\text { Non-farm wage and salary employment, } \\
1995^{1}\end{array}$ & $3,9006.322$ & $141,326.104$ & 33.000 & $4,064,479.000$ \\
\hline $\begin{array}{l}\text { Non-farm wage and salary employment, } \\
\quad 2000^{1}\end{array}$ & $43,657.588$ & $158,201.721$ & 45.000 & $4,401,549.000$ \\
\hline $\begin{array}{l}\text { Non-farm proprietors employment, } \\
1985^{1}\end{array}$ & $5,316.171$ & $17,817.205$ & 22.000 & $608,798.000$ \\
\hline $\begin{array}{l}\text { Non-farm proprietors employment, } \\
1990^{1}\end{array}$ & $6,223.101$ & $22,253.084$ & 13.000 & $795,493.000$ \\
\hline $\begin{array}{l}\text { Non-farm proprietors employment, } \\
1995^{1}\end{array}$ & $7,094.365$ & $25,591.451$ & 41.000 & $946,983.000$ \\
\hline Wage and salary per job, $1985^{1}$ & $14,541.356$ & $3,117.283$ & $7,918.675$ & $32,017.196$ \\
\hline Wage and salary per job, $1990^{1}$ & $17,358.212$ & $3,715.082$ & $9,828.829$ & $40,526.019$ \\
\hline $\mathrm{w}$.uselectionatlas.ors & (2) & 20 & & is Resear \\
\hline
\end{tabular}

on lagged net proprietorship formations, changes in wage-and-salary earnings per job, lagged wage-and-salary employment growth, and rural-urban indicators (Equation 1). ${ }^{3}$

$$
\Delta \mathrm{E}=\alpha+\beta_{1} \Delta \mathrm{E}_{-1}+\beta_{2} \Delta \mathrm{S}_{-1}+\beta_{3} \Delta \mathrm{W}_{-1}+\beta_{5} \mathrm{M}_{0}+\varepsilon,
$$

where $(\Delta E)$ is the dependent variable, defined as the percent change in wage-and-salary employment. For instance, for 2000-2004, it is calculated as

(2) $\quad[\text { (No. of non-farm wage-and-salary jobs })_{2004} /$ (No. of non-farm wage-and-salary jobs $\left.)_{2000}-1\right] * 100$,

and analogously for the other time periods and the lagged independent variables $\left(\Delta E_{-1}\right)$. Lagged growth in the dependent variable $\left(\Delta E_{-1}\right)$ picks up the inherent momentum or path dependency that exists within each county based on past growth. Counties that experienced job growth in the last period likely also experienced job growth in the current period. Therefore, we expect a positive coefficient estimate on this covariate.

The variable of central interest is $\left(\Delta S_{-1}\right)$. Proprietorship growth can be measured using the Business Stock (BS) or Labor Market (LM) approaches (Garofoli 1994; Van

\footnotetext{
${ }^{3}$ Van Stel and Storey (2004) also include population density. Population density and metropolitan status of counties are highly correlated, so that population density is not statistically significant in the basic models. As suggested by an anonymous reviewer, we retain only the metropolitan status variable in our analyses.
} 
Stel and Storey 2004). These two approaches differ in the assumptions about the initial pool from which the new proprietors arise. The BS approach normalizes growth in proprietorships by the initial stock of businesses, while the LM approach normalizes it by the initial stock of workers. The LM approach is generally preferred to the BS method because the latter inflates the proprietorship growth rate, especially in regions with fewer firms. Following Van Stel and Storey (2004), we also adopt the LM approach and define proprietorship growth as in Equation (3), and analogously for the other time periods:

$$
\left[\left((\text { Non-farm proprietors })_{1999}-(\text { Non-farm proprietors })_{1995}\right) /\right. \text { Total }
$$
employment $\left._{1995}\right]^{*} 100$.

As discussed earlier, the direction of the effect $\partial(\Delta E) / \partial\left(\Delta \mathrm{S}_{-1}\right)$ is indeterminate $a$ priori. A second key covariate in the base model is the change in wage-and-salary earnings per job over the same lagged period $\left(\Delta W_{-1}\right)$. It is defined as:

$$
\left[\left(\text { Total wages and salary/job) }{ }_{1999} /(\text { Total wages and salary/job })_{1995}-1\right]^{* 100}\right. \text {. }
$$

Here we expect a negative relationship: in counties with greater wage pressure, firms are reluctant to hire additional workers, preferring instead to economize on the scarce factor (see also Pagoulatos, Goetz, Debertin, and Johannson 2004). On the other hand, wage increases provide incentives for the unemployed or underemployed to seek (more) work.

The metropolitan indicator variable $(M)$ is from the USDA's Economic Research Service (ERS). Rural-urban differences both in entrepreneurship development and employment growth are widely reported in the literature (e.g., Goetz and Rupasingha 2007). In the U.S., metro areas have generated a larger share of jobs than rural areas in recent years (adjusted for population), but the costs of doing business increase with population density. The metro variable is a stock variable measured at the beginning of the period over which job growth rates are calculated.

We subsequently expand the basic model (1) by introducing the following covariates to determine whether the effect of growth in proprietors on job creation is robust to the inclusion of additional control variables. These include (a) socio-demographic characteristics such as the percent of adults with a college degree, percent of population foreignborn, ethnic diversity index, social capital; (b) geographical context variables, including interstate highway access, and a natural amenities scale; (c) establishment and industry composition variables, including the number of broadband providers, local connectivity measured as the spatially weighted number of broadband providers, Wal-Mart stores, and high-tech establishments; and (d) political and policy-related variables such as voters' behavior and unemployment compensation insurance.

Educational attainment is measured as the share of adults $(25+$ years $)$ who have completed at least a bachelor's degree. Education is commonly used to proxy for labor quality, and it is expected to positively affect employment growth; more-educated 
workers also have a higher propensity to seek employment. The percent of population that is foreign born may influence job growth through social networks that make it easier to secure employment, as well as greater openness to differences and new ideas (Florida 2002), so we expect a positive relationship between the share of foreign-born population and local job growth. Ethnic diversity is measured as $1-\sum_{i}\left(\text { Race }_{i}\right)^{2}$, where Race $_{i}$ is the share of population self-identified as: White, Black, Asian and Pacific Islander, American Indian or Other. This index measures the odds that two individuals drawn at random from a county are of the same race (Rupasingha, Goetz, and Freshwater 2006). The effect of ethnic background on employment growth operates through two major forces: the intrinsic cultural attitude towards labor supply, which is difficult to judge a priori, and the extent of discrimination in labor markets. Greater ethnic diversity may discourage discrimination in labor markets and encourage labor supply, but this may be offset (or enhanced) by attitudes towards job seeking. Edmiston (2006) finds statistically significant effects across race in his employment model.

Geographical context variables, such as interstate highway access, and amenity scale capture the inherent regional variations that influence employment growth. Counties rich in amenities attract seekers of leisure activities at the local level and generate jobs to meet the demand for goods and services. Interstate highway connections not only decrease the cost of conducting business but also encourage commuting over greater distances to work, so that we expect a positive impact on job growth.

High-tech establishment data as defined in Goetz and Rupasingha (2002) are from County Business Pattern CD-ROMs. The number of Wal-Mart stores captures the presence of big-boxes as compiled in Goetz and Swaminathan (2006) and is from the Rand McNally Road Atlas sold in the chain. The presence of broadband providers is expected to facilitate job search and networking, as well as Internet-based self-employment efforts generally. To capture local connectivity, the spatially weighted number of broadband providers also is included. The social capital stock index is the first principal component of a vector of social capital-generating establishments (bowling alleys, golf courses, membership associations, etc.), non-profit organizations, voter participation in national elections, and participation rates in the 2000 Census of Population (Rupasingha, Goetz, and Freshwater 2006). Industry diversification is another relevant covariate. Hammond and Thompson (2004) find that regional specialization in single industries increases regional employment instability. A positive effect of diversification of economic structure in the context of urban Canada is reported by Coffey and Shearmur (1998). The greater the industrial diversification - the more even the distribution of employment across industrial sectors - the greater the job opportunities provided for workers of diverse skills. The diversity index is $1-\sum_{i}\left(\text { Industry }_{i}\right)^{2}$, where Industry $y_{i}$ is the share of agriculture/mining; construction; manufacturing; wholesale trade; retail; transportation and public utilities; finance, insurance and real state; public administration; services; and other industries, including employment in the information sector. We expect the employment growth impact of industry diversification to be positive. 
Voting behavior reflects the degree of conservatism in a community and the extent to which new and expanding businesses face local barriers to entry. Here we use the share of voters favoring the Republican or conservative candidate in the 2000 presidential election. We are not aware of prior studies that have attempted to test this hypothesis. Unemployment compensation insurance (UCI) is another policy variable, measured in dollars per capita. This is relevant because individuals differ in their attitudes towards career choices in terms of being self-employed, paid employed, or unemployed. UCI provides an incentive for workers to be unemployed and also encourages them to change jobs if they are threatened with a lay-off (Edmiston 2006). We expect the employment effect of UCI to be negative.

\subsection{Estimation Issues}

Van Stel and Storey (2004) and others (such as Davidsson, Lindmark, and Olofsson 1994; Edmiston 2006) ignore the possible spatial dependency of job growth. Because our unit of observation is the county, we have reason to suspect spatial dependence bias due to measurement error (Anselin 1998; LeSage 1999) and because labor markets in one county are related to those of neighboring counties. Wheeler (2001) points out that economic actors prefer to cluster spatially so as to reduce costs associated with conducting business and to provide greater access to workers. Another reason for spatial correlation is the fact that growth disperses itself spatially. Wheeler (2001) provides evidence that employment is not spatially independent. Similarly, Baptista, Escaria, and Madruga (2005) and MuellerVan Stel, and Storey (2006) find positive spatial autocorrelation in employment growth, and we expect to find the same.

Spatial dependency may operate through spatial lags both in the dependent variable and error terms. A general form of the spatial model with one spatial weights matrix $(W)$ that nests both the spatial lag and spatial error models takes this form (LeSage 1999):

$$
Y=\rho W(Y)+X \beta+\mu, \quad \mu=\lambda W \mu+\varepsilon \quad \varepsilon \sim N\left(0, \sigma_{\varepsilon}^{2}\right)
$$

where $Y$ is a $n \times 1$ vector of observations on the dependent variable, $\rho$ a spatial autoregressive parameter (or spatial autocorrelation coefficient if $W$ is row-standardized), $W$ a spatial weights matrix of dimension $n \times n, W Y$ is the spatially lagged dependent variable, $X$ an $n \times k$ matrix of observations of exogenous variables, $\beta$ a $k \times 1$ vector of parameters to be estimated, $\lambda$ the spatial autoregressive parameter similar to $\rho$ for the error lag $W \mu$, and $\varepsilon$ is an $n \times 1$ vector of innovations. Inclusion of spatially lagged dependent variable as a regressor can cause serious endogeneity problems (both bias and inefficiency) if ordinary least squares estimators are used (Kim, Phipps, and Anselin 2003; 
Anselin 1998). ${ }^{4}$ Depending on the way in which the spatial dependency operates, the general model can be simplified into a spatial lag or spatial error model. If $\lambda=0$ and $\rho \neq$ $0, \mu=\varepsilon$ the spatial lag model is appropriate. On the other hand, $\lambda \neq 0$ and $\rho=0, \mu \neq \varepsilon$ implies that the spatial error model is appropriate. If $\lambda=0$ and $\rho=0, \mu=\varepsilon$ and OLS is appropriate. If $\lambda \neq 0$ and $\rho \neq 0, \mu \neq \varepsilon$ and this implies a more general model. Here we follow the decision rule of selecting among spatial models given in Anselin (2005). The spatial models are estimated using maximum likelihood methods.

Further, unlike Van Stel and Storey (2004), we estimate state-level fixed effect models. ${ }^{5}$ These models control for unobserved heterogeneity at the state level, such as state-specific policies that affect job growth. This model assumes that covariates and heterogeneity (unobserved variables) are not orthogonal (Wooldridge 2002). The relevant spatial model with state fixed effects over the spatial model without state fixed effects is tested using Likelihood Ratio tests (Wooldridge 2002).

\section{RESULTS}

\subsection{Spatial Spill-Over in Job Growth}

Both exploratory analysis and formal tests of spatial dependency using a "queen" contiguity spatial weighting matrix confirmed the existence of spatial dependency in job growth. Queen contiguity is defined as $w_{i j}=1$ if one county shares a common side or vertices with its neighboring counties and 0 otherwise. Figures 2 through 5 illustrate the spatial clusters and outliers for job growth rates in four different periods. The High-High shading shows spatial clusters of hot spots - counties with high job growth surrounded by neighbors with high job growth, and Low-Low shading show spatial clusters of cold spots - counties with low job growth surrounded by neighbors with low job growth. In fact, spatial clustering of job growth is apparent in all periods, but the locations of hot and cold spots shift over time.

In 1985-1989, clusters of high job growth rates were observed in southern California, most parts of Nevada, western Arizona, and the east coast, especially central Florida, Maryland, and northeast Virginia as well as northern Michigan, Georgia, Kentucky, and southern Missouri, while clusters of low job growth were concentrated in the midwest. However, in 1990-1994 the patterns show a shift. Both the east and west coasts, which

\footnotetext{
${ }^{4}$ One way of circumventing this problem is to use maximum likelihood estimators (Anselin 1998). Alternatively, Kelejian and Prucha (1999) propose an instrumental variables approach to deal with this problem. We use the ML method; therefore this problem is not an issue in the estimation. The use of an OLS estimator in a spatial error model results in unbiased but inefficient parameter estimates (Anselin 1998). Again, this problem can be addressed either using the ML method (Anselin 1998) or generalized moment method as proposed by Kelejian and Prucha (1999). Since we have used the ML method, this is not an issue.

${ }^{5}$ This was suggested by anonymous reviewer. Application of a fixed effects model resulted in redundancy of some of the variables that are used in literature, such as census regions, state-level union density, and state-level workers' compensation benefits.
} 
prospered during the previous period, lagged behind during this period. Southern Utah, Colorado, northern Arizona, and New Mexico including northwest Wyoming prospered, while clusters of low job growth appeared in the northeast - especially Maine, Massachusetts, Connecticut, Rhode Island - and New Mexico contained. In 1995-1999, the patterns again shifted. Both the east and west coasts stood out for their strong job growth patterns and they remained strong in 2000-2004 even as the overall U.S. economy declined. Southern Texas, southern Wyoming, western parts of Montana, and parts of Washington state, which did not experience rapid job growth in the earlier three periods, grew rapidly in 2000-2004, largely because of the booming energy sector.

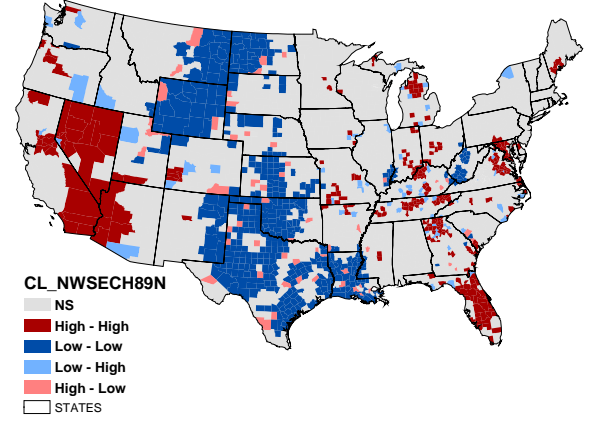

FIGURE 2. Clusters of Percent Non-Farm Wage-and-Salary Job Growth, 1985-1989

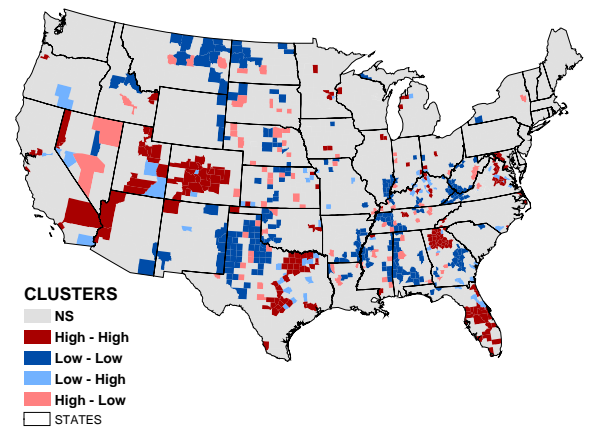

FIGURE 4. Clusters of Percent Non-Farm Wage-and-Salary Job Growth, 1995-1999

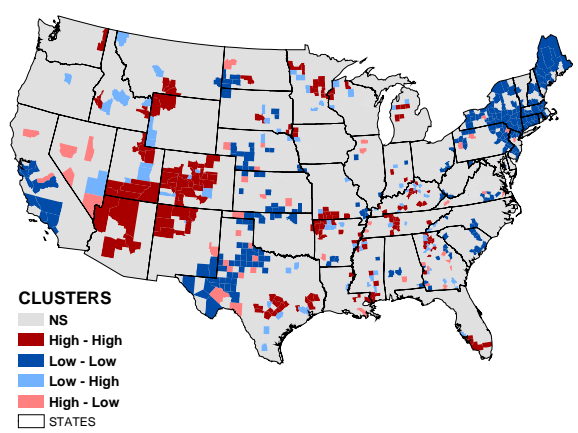

FIGURE 3. Clusters of Percent Non-Farm Wage-and-Salary Job Growth, 1990-1994

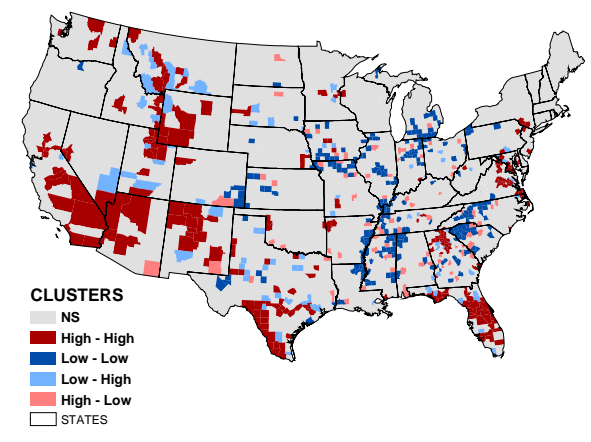

FIGURE 5. Clusters of Percent Non-Farm Wage-and-Salary Job Growth, 2000-2004 
TABLE 2

Test of Spatial Dependency of Non-Farm Wage-and-Salary Job Growth

\begin{tabular}{|c|c|c|c|c|}
\hline \multirow{2}{*}{ Tests } & \multicolumn{3}{|c|}{ Base Model } & \multirow{2}{*}{$\begin{array}{c}\text { Expanded } \\
\text { Model } \\
2000-2004 \\
\end{array}$} \\
\hline & 1990-1994 & 1995-1999 & $2000-2004$ & \\
\hline Moran's I (Unconditional) & 0.046 & 0.181 & 0.182 & 0.182 \\
\hline Moran's I (Conditional) & $0.042^{* *}$ & $0.107^{* *}$ & $0.142^{* *}$ & $0.124^{* *}$ \\
\hline LM Error & $11.657^{* *}$ & $91.979^{* *}$ & $162.114^{* *}$ & $122.480^{* *}$ \\
\hline LM Lag & $12.074^{* *}$ & $125.563^{* *}$ & $188.449^{* *}$ & $116.932^{* *}$ \\
\hline Robust LM Error & 0.022 & $9.454^{* *}$ & $3.868^{* *}$ & $16.604^{* *}$ \\
\hline Robust LM Lag & 0.438 & $43.037^{* *}$ & $30.202^{* *}$ & 1.056 \\
\hline Appropriate model & Spatial Lag & Spatial Lag & Spatial Lag & Spatial Erro \\
\hline
\end{tabular}

The significant Moran's I statistics in Table 2 provide strong evidence of spatial dependency of job growth in all three periods, which is also substantiated by the statistically significant asymptotic Lagrange Multiplier (LM) error and LM lag test results. Results of the LM error and LM lag tests along with their robust forms suggest that the spatial lag model is appropriate for the base models. Interestingly, according to Anselin's criteria the spatial error model is a better choice for the expanded models. Therefore, we used a spatial lag correction model for the basic models that adds an additional term, i.e., $W^{*}(\Delta E)$ to the regression, to reduce spatial dependence bias.

\subsection{Basic Analysis}

Spatial regression results with state fixed-effects for the basic models across the three time periods are reported in Table 3..$^{6}$ The likelihood ratio (LR) test showed that the spatial lag model with state fixed effects outperforms the spatial lag model without statefixed effects. ${ }^{7}$ Compared to the spatial model without state fixed effects, the size of the coefficient especially of the spatial lag parameter is substantially smaller (and in fact not significant in 1990-1994), suggesting that state-fixed effects in part capture the spatial dependency in job growth. On the other hand, the size of the effects of lagged proprietorship growth slightly increased in all three periods analyzed compared to the model without fixed effects. As hypothesized, counties with higher lagged job growth

\footnotetext{
${ }^{6}$ The spatial lag coefficient estimates in the table do not capture the total marginal effects of the explanatory variables. These are both direct and induced effects that arise from spatial spillover to neighboring counties and "spillback" to the same county (Kim, Phipps, and Anselin 2003). For an explanatory variable this effect can be calculated as $\beta *[1 / 1-\rho]$. Note that in the case of the spatial error models used to estimate the expanded models (Table 4 and Column 4 in Table 5), the $\beta$ coefficients represent the marginal effect (for details see Kim, Phipps, and Anselin 2003).

${ }^{7}$ LR statistics for the periods studied (2000-2004, 1995-1999, and 1985-1989) are, respectively, 202.6, 122.2, and 144.8. These statistics exceed the chi-squared critical value of 82.72 at 47 degrees of freedom at $p=0.001$.
} 
also experienced faster job growth in the period examined, indicating a positive path dependency of local employment growth. For example, every one percentage point increase in the job growth rate in the period (1995-1999) led to a 0.135 percentage point higher growth rate in 2000-2004. The effect was about one-fourth as small in 1995-1999 (0.028 percentage points) and about two-thirds in 1990-1994 (0.089 percentage points) as the national economy was coming out of the recession and entering into one of the longest expansion in U.S. history.

In 2000-2004, counties experiencing wage pressure in the previous periods saw jobs expand at a lower rate in the subsequent period: each one percentage point increase in wages in the earlier period reduced the job growth rate by 0.041 percentage points in the subsequent period. ${ }^{8}$ Thus, counties with larger earnings increases were penalized by experiencing lower subsequent job growth. This size of the effect was higher by 50 percent in 1995-1999 - and unexpectedly positive - but about the same in 1985-1989 as in 1995-1999.

Next we turn to the covariate of primary interest, growth in proprietorships. Table 3 shows that this variable unambiguously and in a statistically significant manner increased the rate of growth of non-farm wage-and-salary jobs. For each one percentage point increase in the change (growth) in the number of proprietors per total workforce in the lagged period (1995-1999) at the sample mean, the overall rate of job growth increased by over 0.253 percentage points in 2000-2004. ${ }^{9}$ The equivalent percentage is 0.74 percentage points in both 1995-1999 and 1990-1994. The larger job growth impact of proprietorship formation in the earlier two periods compared to the last period studied may be due to the recession.

In 1995-1999, metropolitan counties experienced more rapid job growth (4.5 percentage points higher) than non-metro counties, but the discrepancy fell to one-half that amount in 2000-2004. The spatial lag coefficients in the 1995-1999 and 2000-2004 periods are positive and highly significant, confirming strong spatial spill-over of employment growth from and to neighboring counties. In the 1990-1995 period, the spatial lag coefficient was significant only when the model was estimated without state fixed effects, and the significance of the coefficient disappeared when the model was estimated with state fixed effects.

\footnotetext{
${ }^{8}$ The average value of wage and salary earnings per job in the base year of the lagged period (1995) is $\$ 14,541$, and the average wage and salary employment in the base year (2000) is 43,658 jobs. In terms of a one percent change from the mean value in the base year, an increase in earnings per job by $\$ 145$ in the previous period results in a reduction in wage and salary employment in the following period of $0.04 * \$ 437=17$ jobs.

${ }^{9}$ The total marginal effect is $0.253 * 1 /(1-0.159)=0.301$. Evaluated at the sample mean increase of 71 proprietors and the sample mean number of wage-and-salary jobs of 437 in the base year, this works out to $(0.301 * 437)=131$ additional total wage-and-salary jobs resulting from the increase in proprietorships.
} 
TABLE 3

Determinants of Non-Farm Wage-and-Salary Job Growth, State Fixed Effect Basic Models over Time

\begin{tabular}{|c|c|c|c|c|c|c|}
\hline \multirow{3}{*}{$\begin{array}{l}\text { Variables } \\
\text { Constant }\end{array}$} & \multicolumn{6}{|c|}{ Period } \\
\hline & \multicolumn{2}{|c|}{ 1990-1994 } & \multicolumn{2}{|c|}{ 1995-1999 } & \multicolumn{2}{|c|}{$2000-2004$} \\
\hline & $5.029^{*}$ & $(1.786)$ & $-3.001^{* *}$ & $(-2.399)$ & $-3.243^{* *}$ & $(-3.149)$ \\
\hline $\begin{array}{l}\text { Lagged wage employment } \\
\text { growth, } \Delta E_{-1}\end{array}$ & & & & & & \\
\hline $1985-1989$ & $0.089^{* *}$ & (2.479) & & & & \\
\hline 1990-1994 & & & $0.028^{* *}$ & (3.569) & & \\
\hline 1995-1999 & & & & & $0.135^{* *}$ & $(8.954)$ \\
\hline $\begin{array}{l}\text { Lagged wage earnings } \\
\text { growth, } \Delta W_{-1}\end{array}$ & & & & & & \\
\hline 1985-1989 & -0.048 & $(-0.739)$ & & & & \\
\hline 1990-1994 & & & $0.062^{* *}$ & $(2.011)$ & & \\
\hline 1995-1999 & & & & & $-0.041^{*}$ & $(-1.716)$ \\
\hline $\begin{array}{l}\text { Lagged proprietorship } \\
\text { growth, } \Delta S_{-1}\end{array}$ & & & & & & \\
\hline $1985-1989$ & $0.844^{* *}$ & (5.627) & & & & \\
\hline 1990-1994 & & & $0.841^{* *}$ & $(13.189)$ & & \\
\hline 1995-1999 & & & & & $0.253^{* *}$ & $(8.875)$ \\
\hline Metropolitan county (yes=1) & 0.323 & $(0.328)$ & $4.509^{* *}$ & $(11.837)$ & $2.284^{* *}$ & (6.969) \\
\hline$\rho$ & 0.002 & $(-0.057)$ & $0.193^{* *}$ & $(7.483)$ & $0.159^{* *}$ & (5.969) \\
\hline$R$-squared & 0.069 & & 0.209 & & 0.203 & \\
\hline
\end{tabular}

\subsection{Expanded Analysis}

Next we expanded the basic model for 2000-2004 by introducing a set of relevant covariates $(a)$ to determine whether the coefficient estimates remained robust in the original 2000-2004 model, and (b) to assess the independent effects of other covariates thought to affect spatially diverging job creation patterns. In Table 4, Models I and II show spatial estimates with and without state fixed effects. Model II allows comparisons between the basic and expanded models and an assessment of the robustness of the effect of proprietor's growth on wage and salary job growth. Model III is estimated to determine whether the effect of proprietor growth on job growth varies by metro status of counties. As in the basic models, the LR test results show that the spatial error model with state fixed effects outperforms the spatial error model without state fixed effects (LR test statistics $=108.7$ with $p<0.001$ ).

The coefficient estimate on lagged job growth is reduced from 0.135 in the basic model to 0.085 in the expanded model, whereas the size of the effect of wage earnings 
TABLE 4

Determinants of Non-Farm Wage and Salary Job growth, 2000-2004 [Expanded Model]

\begin{tabular}{|c|c|c|c|c|c|c|}
\hline \multirow[b]{3}{*}{ Variable } & \multicolumn{6}{|c|}{ Spatial Error Model } \\
\hline & \multicolumn{2}{|c|}{ Model-I } & \multicolumn{2}{|c|}{$\underline{\text { Model-II }}$} & \multicolumn{2}{|c|}{ Model-III } \\
\hline & Coeff. & z-stat & Coeff. & z-stat & Coeff. & Z-stat \\
\hline Constant & $-24.695^{* *}$ & -5.606 & $-34.816^{* *}$ & -7.414 & -34.795 & -7.413 \\
\hline Lagged non-farm wage and salary employment growth, 1995-1999 & $0.057^{* *}$ & 3.694 & $0.085^{* *}$ & 5.578 & $0.085^{* *}$ & 5.543 \\
\hline Lagged proprietorship growth, 1995-1999 & $0.161^{* *}$ & 5.667 & $0.204^{* *}$ & 7.264 & $0.162^{* *}$ & 4.486 \\
\hline Lagged wage earning growth, 1995-1999 & $-0.068^{* *}$ & -2.924 & $-0.048^{* *}$ & -2.036 & $-0.050^{* *}$ & -2.100 \\
\hline Metropolitan county & $1.135^{* *}$ & 2.951 & $1.340^{* *}$ & 3.531 & $1.062^{* *}$ & 2.592 \\
\hline Lagged proprietorship growth, 1995-1999* Metro County & & & & & $0.099^{*}$ & 1.800 \\
\hline Percent population with at least bachelor's degree, 2000 & $0.272^{* *}$ & 8.363 & $0.344^{* *}$ & 10.428 & $0.346^{* *}$ & 10.489 \\
\hline Percent population foreign born, 2000 & $0.135^{* *}$ & 2.932 & 0.048 & 1.011 & 0.048 & 1.013 \\
\hline Ethnic diversity Index, 2000 & $-3.177^{* *}$ & -2.508 & $-4.244^{* *}$ & -2.813 & $-4.234^{* *}$ & -2.807 \\
\hline Social capital index, 1997 & $-0.949^{* *}$ & -5.735 & $-1.423^{* *}$ & -7.642 & $-1.431^{* *}$ & -7.686 \\
\hline Share of vote for Bush, 2000 & $0.043^{* *}$ & 2.728 & $0.036^{* *}$ & 2.103 & $0.035^{* *}$ & 2.058 \\
\hline Per capita unemployment insurance compensation (\$), 2000 & $-0.008^{* *}$ & -2.205 & -0.002 & -0.543 & -0.002 & -0.519 \\
\hline High_tech establishments, 1999 & $-0.006^{* *}$ & -3.956 & $-0.006^{* *}$ & -4.177 & $-0.006^{* *}$ & -4.169 \\
\hline Number of broadband suppliers & 0.007 & 1.073 & 0.006 & 1.021 & 0.006 & 1.013 \\
\hline Spatially weight*Number of broadband suppliers & 0.001 & 0.244 & 0.0002 & 0.051 & 0.000 & 0.016 \\
\hline Number of Wal-Mart stores, 1998 & -0.051 & -0.402 & -0.028 & -0.218 & -0.019 & -0.147 \\
\hline Industry diversity index, 2000 & $23.229^{* *}$ & 4.262 & $32.300^{* *}$ & 5.849 & $32.389^{* *}$ & 5.869 \\
\hline Amenity scale (McGranahan) & $0.217^{* *}$ & 2.425 & $0.230^{*}$ & 1.887 & $0.243^{* *}$ & 1.992 \\
\hline County with highway connection, 2000 & 0.263 & 0.791 & 0.098 & 0.299 & 0.108 & 0.328 \\
\hline$\lambda$ & $0.264^{* *}$ & 10.084 & $0.140^{* *}$ & 5.007 & $0.141 * *$ & 5.030 \\
\hline R_Squared & 0.187 & & 0.224 & & 0.249 & \\
\hline -Log Likelihood & $10,504.2$ & & $10,451.8$ & & $10,450.2$ & \\
\hline
\end{tabular}


growth is relatively robust to the specification change (third column in Table 3 and Model II in Table 4). The size of the effect of lagged proprietorship growth is decreased by 0.05 percentage points in the expanded model as compared to the basic model (from 0.253 to 0.204 ). ${ }^{10}$ We also add an interaction term (metro* proprietors growth) to determine whether proprietorship formations in metro areas exert an independent, additional positive or negative effect (Model III in Table 4). While this makes a direct comparison of results with the previous estimate impossible (third column in Table 3), we do find a statistically significant effect of both proprietorship growth and the interaction term (at the 10 percent level). The interaction term with metropolitan areas suggests that these areas enjoy an additional, independent boost over non-metro areas from lagged proprietorship growth. Ceteris paribus, metro counties experienced an additional 0.1 percentage point increase in jobs. ${ }^{11}$

Socio-demographic factors affect job growth in important ways. The greater the share of foreign born and college graduates the higher the rate of job creation, ceteris paribus. However, the foreign born effect is not robust when state fixed effects are included, or when the metro*proprietors interaction term is included. In contrast, increased ethnic diversity reduces job growth, a contrary and potentially controversial finding in the current immigration debate. Similarly, counties with greater social capital stocks experienced less job expansion, raising the possibility of reverse causality. In other words, social capital stocks may rise in communities that are in economic decline.

To our knowledge this is the first study to empirically examine the effect of voting behavior on local job growth. Counties with a greater share of voters favoring President George W. Bush or the Republican Party in the 2000 national election experienced higher job growth. As expected, per capita unemployment insurance compensation is negatively related to job growth, but these coefficients are not statistically significant in the state fixed effects model. (They are significant in the model without state fixed effects.)

Indicators of technology and high-tech industrial establishments are also important in job growth. Contrary to expectations, however, greater presence of high-tech establishments was associated with significantly lower job growth rates, rather than accelerated growth; clearly, this result is especially sensitive to the time period studied. The availability of broadband providers in the county did not significantly affect job growth. As expected, the spatially weighted broadband variable that captures local connectivity shows a positive effect, but it is not strong. Counties with Wal-Mart stores at the beginning of the period over which growth is calculated (lagged to 1998 because of data

\footnotetext{
${ }^{10}$ Controlling for all other factors, each one percentage point increase in proprietorship growth i.e., 71 proprietors from the mean in the base year of the lagged periods - increases wage and salary jobs by 0.20 percent, i.e., 87 jobs.

${ }^{11}$ These are 44 additional jobs over the mean for each one percent increase in additional proprietors in previous periods - i.e., 71 additional proprietors from the mean - as compared with rural counties.
} 
availability), experienced a reduction in non-farm wage-and-salary employment growth rate during 2000-2004, but this effect was not statistically significant. The industry diversity index - measured in terms of employment in different industrial sectors - shows that the greater the industrial diversity at the beginning of the period the more rapid the subsequent job growth, so that industrial diversification is favorable for job growth.

Counties rich in amenities tend to enjoy higher rates of job creation. Highway access did not have a significant effect. Job growth in neighboring counties positively affects job growth: even after controlling for other relevant variables, the spatial spill-over effect of job growth is strong, suggesting that failure to account for spatial dependency in job growth may bias the estimates. However, the bias is trivial in the case of the size of the coefficient of lagged proprietorship growth, i.e., a 0.001 percentage point decline with the spatial error model over the OLS model. ${ }^{12}$ Even so, the coefficients of most other variables are substantially altered.

\subsection{Lag Effects}

The effect of proprietorship formation on job creation may not be immediate. Van Stel and Storey (2004) estimate the long-run effect by introducing different lags of firms' births. They find strong inter-temporal correlation between firm birth rates (at least $r=0.9$ ) and address the multicollinearity problem by imposing restrictions using the Almon method with a polynomial of second degree. In our data, the inter-temporal correlation between proprietorship formation rate is not as strong ( $r=0.08$ to 0.23 ). Therefore, instead of using restricted models, we estimated unrestricted models for both basic and expanded models for 1995-1999 and 2000-2004. Except for the additional lag terms, the variables included in the models are same as those in Table 3 (Basic Models) and Table 4 (Expanded model). We report only the coefficient for the lag terms (Table 5).

Each one percentage point increase in proprietors per total workforce in 1985-1989 yields a 0.60 percentage point increase in jobs in 1995-1999. The impact increases to 0.74 percentage point for each one percentage point addition of proprietors in 1990-1994, indicating that the short-run impact of proprietorship formation on job creation exceeds the long-run impact. This is contrary to our expectations. Plausibly this could be due to the limited number of time periods considered in the analysis, and in part it also could reflect the business cycle. In contrast, in the 2000-2004 basic and expanded models the impact first increases with the lags and then declines. The same is true for the 1995-1999 period. Both short-run and long-run impacts of proprietorship growth on job creation are substantially higher in the 1995-1999 than the 2000-2004 model, which again likely reflects differences in the state of the economy.

We estimated a series of other models to evaluate the robustness of the coefficient estimates. Inclusion of an interaction term between proprietorship growth in the lagged period and metro status of counties reduced the size of the effect of lagged proprietorship

\footnotetext{
${ }^{12}$ Tables with detailed results are available from the lead author upon request.
} 
TABLE 5

Lag Effects of Proprietorship Formation on Non-Farm Wage-and-Salary Job Growth

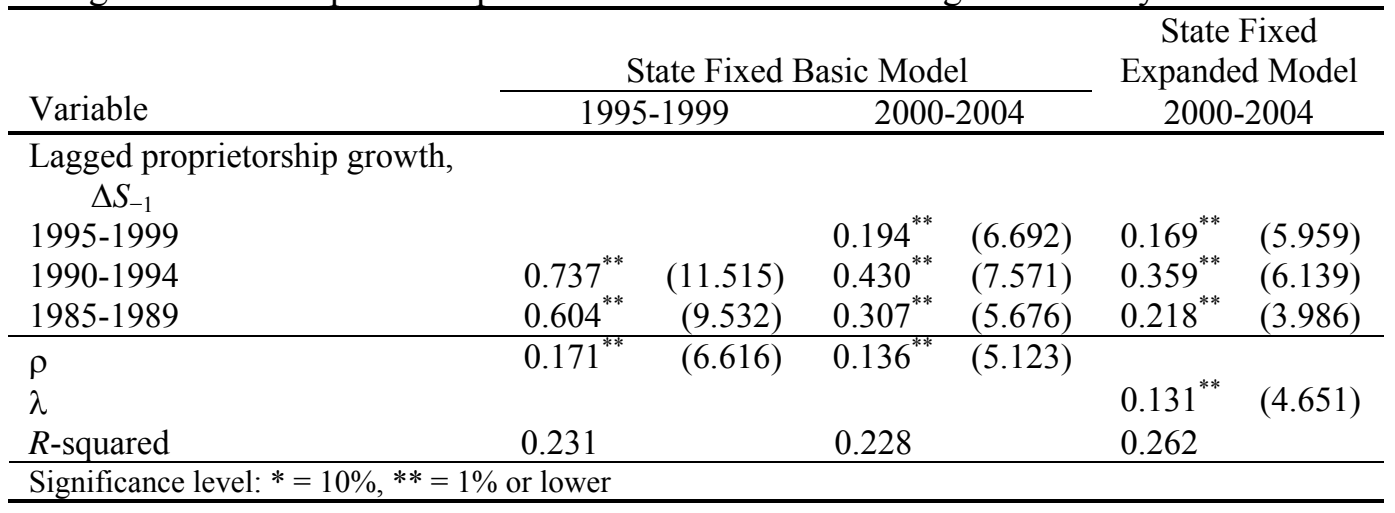

growth by 0.04 percentage points for each additional one percentage point increase in proprietorship growth. Models with and without the voting shares revealed that inclusion of this variable also increased the size of the effect of lagged proprietorship growth by 0.04 percentage points. ${ }^{13}$ The LR test results show that the model including voting behavior is statistically superior to the model without this variable at the 5 percent level of significance (LR test score $=4.42>\chi^{2}(1)$ at $0.05=3.84$ ). Inclusion of the voting variable also noticeably decreases the coefficient estimates of the ethnic diversity index and industry diversification variables.

\section{CONCLUSIONS}

We examine the extent to which the rate of growth of non-farm wage and salary employment is influenced by proprietorship formations (lagged growth in non-farm proprietors per 100 stock of workers) using U.S. county-level data. We adapted the work of Van Stel and Storey (2004) to the U.S. context, but our work differs from theirs in significant ways because we address spatial bias and also examine the effects of several additional covariates, including the slope effect of metropolitan counties relative to nonmetropolitan counties. Further, we find that a state fixed effects model is appropriate.

Our results provide unequivocal support for the argument that lagged proprietorship formations lead to increased job growth, controlling for other factors and regardless of the time period considered. Notably, the relationship appeared to be stronger when the U.S. economy was recovering from a recession and smaller when it was in recession. Another key impact on this relationship was the metropolitan and non-metropolitan status of counties in the most recent period studied (2000-2004). Metropolitan counties experienced an additional boost over non-metro counties in terms of jobs created per additional proprietors in 1995-1999. The effect of proprietorship formation on job growth increases

${ }^{13}$ These results are available upon request. 
with time but then declines, and the effect also depends on the period studied. Additionally, our results provide strong evidence of spatial dependency of job growth, which is ignored in many studies including Van Stel and Storey's (2004), suggesting that failure to account for spatial autocorrelation of job growth may yield biased estimates. However, it appears that the estimate of lagged proprietorship growth is not affected by this phenomenon.

The positive path dependency of employment in our results is consistent with Van Stel and Storey's (2004) work. Interestingly, we find a job growth impact of lagged wage growth (negative) that is opposite to theirs (positive). This could be due to differences in the measure of our wage variable. Most importantly, while we find a positive impact of proprietorship formation on job growth regardless of time period studied, they obtain mixed (even negative) results over time and across regions. This difference may be attributed to differences in industrial structure, including size of firms and state of economic growth between the two economies, which are difficult to measure and model.

Among the socio-demographic factors, share of adult population with a college degree, share of foreign-born population, and ethnic diversity are important in explaining job growth. While a larger share of college graduates and foreign-born population benefits local job growth, ethnic diversity has a negative effect. For the political and policy variables, counties with a greater share of voters favoring George W. Bush in the 2000 national election experienced higher job growth rates. We caution that this does not necessarily mean that the presence of voters favoring the Republican Party increases job growth. Unmeasured prosperity in counties with higher job growth may be correlated with pro-Republican voting, and we do observe positive path dependency of job growth. Our study did not confirm recent research in other contexts that suggests Wal-Mart's expansion and the associated employment efficiencies stifle overall job creation. This could be partly because we control for state fixed effects, and the concentration of WalMart varies by state (although the effect is statistically significant when we do not control for fixed effects). Similarly, having more high-tech establishments in the region is not favorable to local job growth, but industry diversification is beneficial.

Overall, we conclude that policies supporting entrepreneurship at the local level stimulate local job growth, and that may reduce local unemployment problems. However, our study does not address what kinds of entrepreneurship (such as size and types) are most beneficial. This question warrants further research.

\section{REFERENCES}

Acs, Z. and C. Armington, 2004. " Employment Growth and Entrepreneurial Activity in Cities," Discussion Paper on Entrepreneurship, Growth and Public Policy \#13/2004, Max Planck Institute for Research into Economic System, Jena, Germany.

Anselin, L., 1998. Spatial Econometrics: Methods and Models. Kluwer Academic Publishers: Dordrect. 
, 2005. "Exploring Spatial Data with GeoDa: A Workbook," Centre for Spatially Integrated Social Science (CSISS), www.geoda.uiuc.edu/documentation. php\#manuals.

Armington, C. and Z.J. Acs, 2002. "Determinants of Regional Variation in New Firm Formation," Regional Studies 36, 33-45.

Atasoy, S., J.C. McConnon, and T. Gabe, 2004. "The Economic Importance and Impact of Microenterprises to the New England Economy," Selected Paper Presented at the Annual Northeast Agricultural and Resource Economics Association meetings, Halifax, Nova Scotia, Canada, June 2004.

Baptista, R., V. Escaria, and P. Madruga, 2005. "Entrepreneurship, Regional Development and Job Creation: The Case of Portugal," Max Planck Institute for Research into Economic System, Working Paper \# 06-2005.

Coffey, W.J. and R.G. Shearmur, 1998. "Factors and Correlates of Employment Growth in the Canadian Urban System 1971-1991," Growth and Change 29, 44-66.

Davidsson, P., L. Lindmark, and C. Olofsson, 1994. "New Firm Formation and Regional Development in Sweden," Regional Studies 28, 395-410.

Deller, S.C., T.H. Tsai, D.W. Marcouiller, and D.B.K. English, 2001. "The Role of Amenities and Quality of Life in Rural Economic Growth," American Journal of Agricultural Economics 83, 352-365.

Edmiston, K.D., 2006. "Workers' Compensation and State Employment Growth," Journal of Regional Science 46, 121-145.

Essletzbichler, J., 2004. "The Geography of Job Creation and Destruction in the U.S. Manufacturing Sector, 1967-1997," Annals of Association of American Geographers 94, 602-619.

Evans, D.S. and L.S. Leighton, 1989. "Some Empirical Aspect of Entrepreneurship," The American Economic Review 79, 519-535.

Florida, R., 2002. The Rise of the Creative Class. Basic Books: New York.

Folster, S., 2000. "Do Entrepreneurs Create Jobs," Small Business Economics 14, $137-$ 148.

Fritsch, M. and P. Mueller, 2004. "The Effects of New Business Formation on Regional Development Overtime," Regional Studies 38, 961-975.

Garofoli, G., 1994. "New Firm Formation and Regional Development: The Case of Italy," Regional Studies 28, 381-393.

Georgellis, Y. and H.J. Wall, 2006. "Entrepreneurship and the Policy Environment," Federal Reserve Bank of St. Louis Review 88 (March/April), 95-111.

Gillis, W. and S. Shahidsaless, 1981. "Effects of Community Attributes on Total Employment Change in Non-Metropolitan Counties," North Central Journal of Agricultural Economics 3, 149-155.

Goetz, S.J. and D.L. Debertin, 2001. "Why Farmers Quit: A County-Level Analysis," American Journal of Agricultural Economics 83, 1010-1023.

Goetz, S.J. and D. Freshwater, 2001. "State-Level Determinants of Entrepreneurship and a Preliminary Measure of Entrepreneurial Climate," Economic Development Quarterly 15, 58-70.

Goetz, S.J. and A. Rupasingha, 2002. "High-Tech Firm Clustering: Implications for Rural Areas," American Journal of Agricultural Economics 85, 1229-1236. 
, 2007. "Determinants and Implications of Growth in Non-Farm Proprietor Densities, 1990-2000," Small Business Economics, forthcoming.

Goetz, S.J. and H. Swaminathan, 2006. "Wal-Mart and Family Poverty in U.S. Counties," Social Sciences Quarterly 83, 211-225.

Greenwood, M.J., 1980. "Metropolitan Growth and the Intrametropolitan Location of Employment, Housing, and Labor Force," The Review of Economics and Statistics 62, 491-501.

Hamilton, B.H., 2000. "Does Entrepreneurship Pay? An Empirical Analysis of the Returns to Self Employment," Journal of Political Economy 108, 604-631.

Hammond, G.W. and E. Thompson, 2004. "Employment Risk in U.S. Metropolitan and Non-Metropolitan Regions: The Influence of Industrial Specialization and Population Characteristics," Journal of Regional Science 44, 517-542

Johnson, T.G., 2001. "The Rural Economy in a New Century," International Regional Science Review 24, 21-37.

Kelejian, H.H. and I. Prucha, 1999. "A Generalized Moments Estimator for the Autoregressive Parameters in a Spatial Model," International Economic Review 40: 509533.

Kim, C.W., T.T. Phipps, and L. Anselin, 2003. "Measuring the Benefits of Air Quality Improvement: A Spatial Hedonic Approach," Journal of Environmental Economics and Management 45, 24-39.

LeSage, J.P., 1999. "Spatial Econometrics," www.rri.wvu.edu/webBook/LeSage/Spatial/ Spatial.html

Long, R.J., 1993. "The Effect of Unionization on Employment Growth of Canadian Companies," Industrial and Labor Relations Review 46, 691-703

Malecki, E.J., 1990. "New Firm Formation in the USA: Corporate Structure, Venture Capital, and Local Environment," Entrepreneurial Regional Development 2, 247265.

Mueller, P., A. Van Stel, and D.J. Storey, 2006. "The Effects of New Firm Formation on Regional Development Over Time: The Case of Great Britain," Discussion Papers on Entrepreneurship, Growth and Public Policy \# 2006-24, Max Planck Institute of Economics, Jena Germany.

Neumark, D., J. Zhang, and B. Wall, 2005. "Business Establishments Dynamics and Employment Growth," http://ssrn.com.

Pagoulatos, A., S.J. Goetz, D.L. Debertin, and T. Johannson, 2004. "Interactions Between Economic Growth and Environmental Quality in U.S. Counties," Growth and Change 35, 90-108.

Parker, S.C., 1996. "A Time Series Analysis of Self Employment Under Uncertainty," Economica 63, 459-475.

Reynolds, P., D.J. Storey, and P. Westhead, 1994. "Cross National Comparison of the Variation in New Firm Formation Rates," Regional Studies 28, 443-456.

Rupasingha, A., S.J. Goetz, and D. Freshwater, 2006. "The Production of Social Capital in U.S. Counties," Journal of Socio-Economics 35, 83-101.

Sobel, R.S. and A.M. Dean, 2006. "Has Wal-Mart Buried Mom and Pop?: The Impact of Wal-Mart on Self Employment and Small Establishments in the United Sates," West 
Virginia University, Unpublished manuscript. www.be.wvu.edu/divecon/econ/sobel/ WalMart/index.htm.

Van Stel, A.J. and D.J. Storey, 2004. "The Link Between Firm Births and Job Creation: Is there a Upas Tree Effect?" Regional Studies 38, 893-909.

Wheeler, C.H., 2001. "A Note on the Spatial Correlation Structure of County-Level Growth in the U.S.," Journal of Regional Science 41, 433-449.

Wooldridge, J.M., 2002. Econometric Analysis of Cross Section and Panel Data. The MIT Press: Cambridge. 